\title{
СПЕЦІАЛЬНО-КРИМІНОЛОГІЧНА ПРОФІЛАКТИКА КОРУПЦІЙНИХ ЗЛОЧИНІВ
}

Кікалішвілі М. В.

Стаття присвячена розгляду спеціально-кримінологічної профілактики корупційних злочинів. У статті наведені визначення поняття спеціально-кримінологічної профілактики злочинності, встановлені істотні елементи зазначеного кримінологічного інституту, а також представлені фактори, які відрізняють спеціально-кримінологічну профілактику від загальносоціальної та індивідуальної профілактики. Автором розкриваються ті завдання, які постають перед спеціально-кримінологічною профілактикою злочинності, наводяться заходи, завдяки яким зазначена профілактика реалізується.

у статті наголошується, що максимальна ефективність у протидії корупційній злочинності можлива за умови системного використання усіх заходів спеціально-кримінологічної профілактики разом. Крім того, встановлено, що спеціальна профілактика корупційної злочинності завжди передбачає використання заходів, які спрямовані на нейтралізацію, блокування криміногенних факторів.

Визначено, що профілактика злочинності є дієвим способом ї̈ поступового викорінення. Спеціально-кримінологічна профілактика корупційної злочинності є одним з найбільш ефективних видів профілактики, адже передбачає безпосередню діяльність органів кримінальної юстиції із недопущення злочинної поведінки в суспільстві та вчинення дій, спрямованих на захист кожного члена суспільства від будь-яких злочинних проявів.

Ключові слова: профілактика, корупційні злочини, спеціально-кримінологічні заходи, кримінологія, нейтралізація криміногенних факторів, ефективність.

Статья посвящена рассмотрению специально-криминологической профилактики коррупционных преступлений. B cтатье приведены определения понятия специально-криминологической профилактики преступности, установлены существенные элементы указанного криминологического института, а также представлены факторы, которые отличают специально-криминологическую профилактику от общесоциальной и индивидуальной профилактики. Автором раскрываются те задачи, которые стоят перед специально-криминологической профилактикой преступности, приводятся меры, благодаря которым указанная профилактика реализуется.

В статье отмечается, что максимальная эффективность в противодействии коррупционной преступности возможна при условии системного использования всех мероприятий специально-криминологической профилактики вместе. Кроме того, установлено, что специальная про филактика коррупционной преступности всегда предполагает использование мер, направленных на нейтрализацию, блокирование криминогенных факторов.

Определено, что профилактика преступности является действенным способом ее постепенного искоренения. Специально-криминологическая профилактика коррупционной преступности является одним из наиболее эффективных видов профилактики, ведь предусматривает непосредственную деятельность органов уголовной юстиции

Кікалішвілі М. В., 2019 по пресечению преступного поведения в обществе и совершение действий, направленных на защиту каждого члена общества от любых преступных проявлений.

Ключевые слова: профилактика, коррупчионные преступления, специально-криминологические меры, криминология, нейтрализация криминогенных факторов, эффективность.

The article is devoted to special-criminological prevention of corruption crimes. In the article there are definitions of the concept of special-criminological crime prevention. Essential elements of the noted criminological institute are established, and also factors of difference of special-criminological preventive maintenance from general social and individual preventive maintenance are found out. The author reveals the tasks that arise before the special-criminological prevention of crime, gives the means by which the marked prevention is realized.

In the article it is paid attention that the maximum efficiency in counteraction to corruption crime is possible under condition of system use of all means of special-criminological prevention together. Besides, it is established that the special prevention of corruption crime always provides for the use of means aimed at neutralization and blocking of criminogenic factors.

As a result, it is determined that crime prevention is an effective way to gradually eliminate it. Special criminological prevention of corruption is one of the most effective types of prevention, as it provides for the direct activities of criminal justice authorities to prevent criminal conduct in society and commit acts aimed at protecting each member of society from any criminal manifestations.

Key words: prevention, corruption crimes, special criminological means, criminology, neutralization of criminogenic factors, efficiency.

Постановка проблеми та її актуальність. Боротьба із корупцією та корупційною злочинністю сьогодні $\epsilon$ однією з найбільш нагальних проблем українського буття. 3 кожним роком питання тотальної корумпованості державних інституцій супроводжується відчуттям неминучості, ніби нічого змінити не можна. Таке враження складається не випадково, адже попри те, хто наразі перебуває на чолі політичної системи чи які вектори державного розвитку закладаються, життя пересічних громадян не змінюється, оскільки вони постійно стикаються з корупційними проявами в різних побутових аспектах. Ще більше здивування викликає та обставина, що деякі держави, які не занадто відрізняються від України ресурсним чи людським потенціалом, змогли успішно подолати корупцію за відносно невеликі строки. Ідеться про такі держави, як Грузія, Латвія, Естонія. Це держави, які об'єднані з Україною історичним минулим радянських часів.

Цікаво, що корупція прямо впливає на стратегічні цілі розвитку нашої держави. Так, зазначене явище істотно заважає розбудувати сильну, незалежну державу із європейськими цінностями, з розвинутою еко- 
номікою, що передбачено відомчими документами Кабінету Міністрів України.

Найбільш істотного удару корупційна злочинність завдає по державній економіці. Вкрай сумно, що реальну небезпеку від такого удару часто неможливо оцінити вчасно, а лише можна констатувати ії масштаб за ступенем завданих збитків, коли це відбувається. Час від часу складається враження, що тіньова економіка в Україні має більшу стійкість, аніж економіка загальнодержавна.

Важливо, що в сучасному науковому світі вже фундаментально доведена неможливість повного викорінення корупції. Вчені зауважують, що зазначене явище має свій прояв в усіх державах світу з різницею лише у рівні поширення. 3 огляду на це в сучасному світі простежується чітка тенденція стосовно необхідності боротися із будь-якою злочинністю на початкових етапах, тобто попереджувати іiі (зрозуміло, що не винятком $\epsilon$ й корупційна злочинність).

Кримінологія розглядає діяльність з попередження злочинів як вплив на чинники, які спричиняють появу та розвиток злочинності в певній сфері, який блокує такі чинники та поступово їх знищує [10, с. 434].

При боротьбі із корупцією величезну роль відіграють ті заходи із попередження цього виду злочинності, які можуть справити позитивний вплив на причини та умови появи зазначених незаконних дій. Такі заходи можуть припинити злочинну діяльність багатьох осіб та сприяти відновленню законослухняного способу життя.

Часто діяльність із попередження злочинності ототожнюється із профілактичними діями. Профілактичну діяльність прийнято поділяти на три окремі великі групи - загальносоціальну профілактику, спеціально-кримінологічну та індивідуальну.

У рамках даного дослідження ми будемо розглядати саме спеціально-кримінологічну профілактику попередження корупційних злочинів, адже даний вид кримінологічної профілактики вважається одним з найбільш дієвих в загальній антикорупційній діяльності держави.

Актуальність нашого дослідження пояснюється тим, що, попри величезну роль профілактичних заходів у загальній протидії корупційній злочинності, зазначені заходи майже не досліджені у вітчизняних наукових колах, а ґрунтовної кримінологічної характеристики спеціально-кримінологічної профілактики корупційних злочинів взагалі неможливо знайти серед об'єктів наукових досліджень. Цей стан речей потрібно змінювати, адже спеціально-кримінологічна профілактика у разі грамотного ії використання може значно покращити ситуацію із корупційною злочинністю в Україні, що $\epsilon$ конче необхідним у контексті прагнення нашої держави бачити себе заможною, сильною та авторитетною в Європі.

Аналіз останніх досліджень і публікацій. Серед вчених, які певним чином в своїх працях торкалися питання щодо дослідження профілактики злочинності загалом та профілактики корупційних злочинів зокрема, треба виділити таких, як О.М. Бандурка, О.М. Джужа, М.І. Мельник, В.В. Голіна, П.В. Цимбал, А.С. Чуйков, А.П. Закалюк, Є.О. Гладкова, В.Н. Кудрявцев.

Метою статті $\epsilon$ дослідження кримінологічної характеристики всіх істотних елементів, що стосуються спеціально-кримінологічної профілактики злочинності загалом та корупційної зокрема, а також визначення того, які заходи спеціально-кримінологічної профілак- тики стосуються безпосередньо попередження корупційної злочинності, з яким рівнем успішності вони працюють наразі в Україні. Задля досягнення поставленої мети необхідно вирішити такі завдання: визначитися із дефініцією поняття «спеціально-кримінологічна профілактика», встановити іiі суттєві відмінності від загальносоціальної та індивідуальної профілактики, дослідити та проаналізувати заходи, через які повинна реалізовуватися спеціально-кримінологічна профілактика корупційних злочинів із визначенням ефективності таких заходів.

Виклад основного матеріалу. Переходячи до викладу основного матеріалу, зазначимо, що саме являє собою спеціально-кримінологічна профілактика злочинності з точки зору кримінології.

Як вже зазначалося, залежно від того, як та за яких умов формується структура злочинності, в їі попередженні (запобіганні) виділяють такі форми: загальносоціальну профілактичну діяльність, спеціально-кримінологічну профілактику та індивідуальну профілактику [9].

Загальносоціальна профілактика зумовлюється розвитком суспільства. Будь-яка злочинність охоплює певні суспільні відносини в конкретній галузі або декількох галузях, які цілком природно розвиваються з часом. Сутність даної профілактичної дії полягає в тому, що суспільство поступово повинно усвідомити недопустимість будь-яких злочинних проявів для подальшого розвитку людства та комфортного життя усіх людей в гармонії. Тобто загальносоціальна профілактика покликана стабілізувати суспільне життя завдяки масштабним просвітницьким діям. Зазначена профілактична дія пов'язана з філософією світосприйняття та багато в чому залежить від зміцнення культурно-моральних принципів кожної особистості.

Індивідуальна профілактика злочинності, в тому числі корупційної, зосереджується на наборі певних дій з боку уповноважених органів, спрямованих на конкретного індивідуума, який своєю поведінкою та зв'язками з оточенням демонструє готовність до злочинної діяльності, з метою корегування негативної свідомості такої особи в позитивному направленні.

Спеціально-кримінологічна профілактика злочинності - це діяльність органів кримінальної юстиції із недопущення злочинної поведінки в суспільстві та вчинення дій, спрямованих на захист кожного члена суспільства від будь-яких злочинних проявів.

В.В. Голіна зауважує, що спеціально-кримінологічна профілактика злочинності - це не просто набір хаотичних дій правоохоронних органів, спрямованих на боротьбу із злочинністю, а сукупність певного комплексу заходів, розроблених спеціально для запобігання подальшому розвитку злочинності та викоріненню вже існуючих їі проявів. Авторка зазначає, що на відміну від загальносоціальної профілактики, яка зосереджує свою діяльність на певному впливі на загальний комплекс негативних явищ в суспільстві, спеціально-кримінологічна профілактика має чітку спрямованість на певні суспільні відносини, в яких спостерігається злочинна тенденція, яку намагаються подолати [1, с. 7].

Спеціально-кримінологічна профілактика спрямована на конкретне недопущення поширення злочинності (має чітко визначену мету) на відміну від індивідуальної профілактики, яка цілеспрямовано діє лише на конкретну особу, а також на відміну від загальносоці- 
альної профілактики, яка займається вивченням теоретичних мотивів появи тієї чи іншої злочинності.

У контексті корупційних злочинів, на думку M.І. Мельника, спеціально-кримінологічна профілактика являє собою діяльність органів кримінальної юстиції із розробки та втілення в життя комплексу заходів спеціального характеру, які спрямовані на усунення, обмеження чи викорінення корупційних чинників, припинення корупційних злочинів (правопорушень), які вчинюються наразі. Спеціально-кримінологічна профілактика корупційних злочинів цілковито спрямована на недопущення подальшого розвитку корупційної злочинності та зменшення рівня наявної злочинності [8, с. 384].

Часто спеціально-кримінологічна профілактика корупційних злочинів проявляється у загальнодержавних програмах, стратегіях, доктринах, планах протидії корупції тощо [7, с. 268].

Попри всі відмінності від індивідуальної профілактики злочинності та загальносоціальної профілактики, спеціально-кримінологічна профілактична діяльність разом 3 ними становить взаємопов'язаний процес загальнопрофілактичних дій, що $\epsilon$ одним зі засобів попередження злочинних проявів. Коли ми говоримо про загальну профілактику, то маємо на увазі всі їі види в сукупності із певним поділом територій впливу.

Кримінологічна наука відрізняється різноманітністю поглядів на класифікацію заходів, які конкретизують спеціально-кримінологічну профілактику злочинності. Під даними заходами прийнято розуміти певні дії, що вчинюються за вектором скорочення конкретного виду злочинів (корупційних злочинів), із визначенням умов та причин вчинення злочинних дій. 3 огляду на це такі заходи можна поділити на загальнодержавні та локальні, а також галузеві, які актуальні для окремих категорій людей, наприклад, державних службовців.

Заходи спеціально-кримінологічної профілактики злочинності $\epsilon$ специфічною категорією, адже саме їх існування зумовлене наявністю злочинності як явища. Зазначені заходи покликані виконувати такі завдання:

- контроль рівня злочинності всередині держави;

- вивчення зарубіжного досвіду протидії певному виду злочинності, а також наукових досліджень стосовно цього виду злочинності;

- розробку та безпосереднє виконання операцій, спрямованих на викорінення злочинних проявів;

- моніторинг проведених заходів;

- формування в пересічних громадян законослухняної моделі поведінки.

В.Д. Малков у своїх дослідженнях зазначав, що спеціально-кримінологічна профілактика корупційних злочинів відбувається в рамках реалізації таких заходів:

- більш якісної регламентації антикорупційних норм, подальшого розвитку антикорупційного законодавства;

- проведення дієвої роботи із чиновниками (забезпечення гідних умов праці та високого рівня контролю за виконанням службових обов'язків);

- більш якісного підбору кадрів, які повинні бути реальними професіоналами своєї справи (зауважується, що особа, заплямована корупційним правопорушенням раніше, або особа, яка постійно порушує етичні норми, не може розраховувати на гідну посаду, адже iii професійна біографія містить негативні відмітки. До речі, актуальним $€$ створення спеціальної служби з підбору кадрів для державних інституцій, яка буде ретельно вивчати кожного кандидата та обирати дійсно кращих);

- розробки загальнодержавних антикорупційних програм щодо протидії корупції;

- підвищення контролю за статками державних службовців (більш ретельне дослідження відомостей, що декларуються державними службовцями);

- захисту осіб, які здійснюють боротьбу проти корупціонерів, від можливого на них тиску (погроз);

- більш якісного співробітництва усіх органів кримінальної юстиції щодо запобігання вчиненню корупційних злочинів на всіх рівнях;

- проведення якісної пропаганди законослухняного способу життя через засоби масової інформації та інші можливі джерела інформації [4].

На думку частини науковців, вкрай ефективним заходом спеціально-кримінологічної профілактики корупційних злочинів могло б стати значне посилення санкцій. Так, доцільно було б частіше застосувати конфіскацію майна як додатковий вид покарання до особи, винної у вчиненні корупційного злочину. Можливість втрати своїх матеріальних благ у сукупності з перспективою відбуття покарання в місцях позбавлення волі повинна застережливо діяти на підсвідомість особи, яка налякана потенційними наслідками, через що така особа цілком може утриматися від вчинення корупційного діяння.

Загалом же, кажучи про ефективність того чи іншого заходу спеціально-кримінологічної профілактики корупційних злочинів, варто пам'ятати, що домогтися цієї ефективності можливо лише при вчасному втручанні, тобто коли реакція відбувається в потрібний період. Також на ефективність певних засобів спеціальної профілактики впливає те, з яким рівнем професіоналізму та завзяття органи кримінальної юстиції підходять до реалізації перелічених вище засобів.

На наш суб' єктивний погляд, найбільш ефективними засобами спеціально-кримінологічної профілактики корупційних злочинів $€$ пропаганда законослухняного способу життя через всі можливі джерела інформації та контроль за статками чиновників. В обох випадках уповноважені органи можуть вчасно втрутитися та попередити вчинення корупційного злочину. Слідкуючи за зростанням статків чиновника, правоохоронний орган контролює, чи не відбувається очевидного порушення співвідношення між реальною заробітною платою та фактичним використанням грошових коштів, що дозволяє своєчасно реагувати та встановлювати особу, відносно якої з'являється підозра у її корумпованості. При цьому цілком природно, що максимальна ефективність у протидії корупційній злочинності можлива за умови системного використання усіх заходів спеціально-кримінологічної профілактики разом.

Заходи спеціально-кримінологічної профілактики корупційної злочинності прийнято умовно поділяти на правові та неправові. До правових належать безпосередньо ті заходи, які передбачені та регламентуються конкретним законом чи нормативно-правовим актом (наприклад, певною статтею Кримінального кодексу України [5]). До неправових заходів належать такі, що не пов'язані із законодавчими приписами. Такими заходами можуть виступати психологічні, педагогічні, організаційній та інші дії, спрямовані на профілактику корупційних злочинів [6, с. 34]. 
Цікаво, що спеціально-кримінологічні заходи профілактики корупційних злочинів можуть вживатися на різних етапах, тобто не тільки після вчинення злочину, а й до того, як особа вдалася до незаконних дій, а також під час вчинення корупційних дій. Головна риса - цільова спрямованість на запобігання злочину на будь-якому етапі його скоєння [2, с. 121].

Спеціальна профілактика корупційної злочинності завжди передбачає використання заходів, які спрямовані на нейтралізацію, блокування криміногенних факторів. До того ж спеціальна профілактика має на меті перевиховання осіб, які вчинили злочин або можуть його вчинити [3, с. 320]. Для ефективного блокування криміногенних факторів та якісного перевиховання злочинців спеціальна профілактика повинна здійснюватися на певних етапах. Так, узагальнено виокремлюють три етапи спеціально-кримінологічної профілактики корупційних злочинів. Це рання, безпосередня та посткримінологічна профілактика.

Рання профілактика спрямована на своєчасне корегування моральних якостей населення з метою недопущення розвитку в останнього злочинного уявлення про життя. Безпосередню профілактику виділяють як складову частину ранньої, адже вона конкретизує ті дії та тих осіб, відносно яких треба проводити профілактичні дії. Посткримінологічна профілактика зосереджується на допомозі особам, які вже відбули покарання за корупційний злочин. Головна задача даного етапу профілактики - не допустити рецидиву [9].

Висновки. Отже, підводячи підсумок всього дослідження, зазначимо, що профілактика злочинності $\epsilon$ дієвим способом їі поступового викорінення. Це вкрай актуально для ситуації із корупцією в Україні. У системі профілактичних дій виокремлюють загальносоціальну, спеціально-кримінологічну та індивідуальну профілактику. Спеціально-кримінологічна профілактика корупційної злочинності $\epsilon$ однією з найбільш ефективних, адже вона передбачає безпосередню діяльність органів кримінальної юстиції із недопущення злочинної поведінки в суспільстві та вчинення дій, спрямованих на захист кожного члена суспільства від будь-яких злочинних проявів. Спеціально-кримінологічна профілактика корупційних злочинів може здійснюватися шляхом реалізації різноманітних заходів, які як окремо, так і разом відрізняються високою ефективністю. Одним з головних завдань будь-якого заходу спеціально-кримінологічної профілактики корупційних злочинів $є$ вчасне виявлення незаконного діяння (чи його готування), а також вчасне встановлення особи, яка готова вчинити злочин або вже це зробила, задля подальшої адекватної реакції, спрямованої на усунення шкідливих наслідків від вчинення корупційного злочину або усунення самого злочину, (якщо це ще можливо зробити).

\section{Література}

1. Голина В.В. Криминологическая профилактика, предотвращение и пресечение преступлений : учеб. пособие. Киев, 1989.

2. Закалюк А.П. Курс сучасної української кримінології: теорія і практика : у 3-х кн. Київ : Видавничий дім «Ін Юре», 2007. Кн. 1 : Теоретичні засади та історія української кримінологічної науки. 424 с.

3. Йосипів А.О. Загальносоціальна, спеціально-кримінологічна та індивідуальна профілактика злочинності: правові аспекти. Науковий вісник Львівськ. держ. ун-ту внутр. справ. Серія «Юридична». 2010. № 1. С. 315-324.

4. Криминология : учебник / под ред. проф. В.Д. Малкова. 2-е изд., перераб. и доп. Москва : ЗАО «Юстиницформ», 2006. 528 c.

5. Кримінальний кодекс України : Закон України від 05.04.2001 р. № 2341-II / Верховна Рада України. Відомості Верховної Ради України (ВВР). 2001. № 25-26. Ст. 131.

6. Литвак О.М. Загальнотеоретичні підвалини соціально-кримінологічного запобігання злочинності. Право України. 2001. № 5. С. 34-37.

7. Мельник М.І. Корупція - корозія влади (соціальна сутність, тенденції та наслідки, заходи протидії) : монографія. Київ : Юридична думка, 2004. 400 с.

8. Мельник М.І. Корупція: сутність, поняття, заходи протидії. Київ : Атіка, 2001. 410 с.

9. Гладкова Є. Протидія злочинності. Вісник кримінологічної асоціації України. URL: https://visnikkau.webnode. com.ua/news/protidiya-zlochinnosti/.

10. Чуйков А.С. Деякі питання спеціально-кримінологічної профілактики легалізації (відмивання) доходів, одержаних злочинним шляхом. Науковий вісник Дніпропетровського державного університету внутрішніх справ. 2013. № 2. C. 433-441. URL: http://nbuv.gov.ua/UJRN/ Nvdduvs_2013_2_61.

Кікалішвілі М. В., кандидат юридичних наук, доцент, доцент кафедри кримінального права та кримінології Київського національного університету імені Тараса Шевченка 